\title{
Pengaruh Komposisi Pembuatan Dodol Mangrove (Sonneratia sp.) Terhadap Uji Organoleptik
}

\author{
Effect of Composition of Mangrove Dodol (Sonneratia sp.) on \\ Organoleptic Test
}

\author{
Lia Fitria \\ Prodi S1 Kebidanan, Fakultas Ilmu Kesehatan, Universitas Ibrahimy \\ Email: liafitria@akbidibrahimy.ac.id
}

\begin{abstract}
ABSTRAK
Mangrove merupakan salah satu tumbuhan yang hidup disepanjang pesisir pantai di Indonesia. Peran dan fungsi mangrove bagi ekosistem sangat penting, selain itu pemanfaatan dibidang ekologi, ekonomi, industri beberapa masyarakat ada yang memanfaatan mangrove sebagai obat dan bahan pangan yaitu pembuatan dodol dan waji. Buah mangrove yang dimanfaatkan pada penelitian ini jenis mangrove Pidada (Sonneratia sp.). Tujuan dari penelitian ini untuk mengetahui pengaruh komposisi pembuatan dodol mangrove (Sonneratia sp.) terhadap uji organoleptik Di Daerah Pesisir Desa Klatakan Kabupaten Situbondo. Penelitian ini merupakan penelitian ekperimen dan rancangan percobaan yang digunakan dalam penelitian ini adalah Rancangan Acak Lengkap (RAL). Perlakuan dalam penelitian ini dilakukan dengan penambahan tepung mangrove $\mathrm{T} 1=$ tidak ada penambahan (kontrol), $\mathrm{T} 2=1 \mathrm{sdm}$ dan $\mathrm{T} 3=2 \mathrm{sdm}$. Analisis statistik dilakukan 2 tahap yaitu univariat dan bivariat. Dalam penelitian ini analisis univariat dilakukan pada tiap variable kemudian dilanjutkan analisis bivariate menggunakan uji Kruskal Wallis. Karakteristik panelis yang akan diuraikan berikut ini menggambarkan keadaan panelis yang diteliti meliputi jenis kelamin, usia dan pekerjaan. Ada perbedaan warna pada 3 perlakuan komposisi pembuatan dodol mangrove (T1, T2 dan T3), sedangkan pada karakteristik rasa dan tekstur tidak terdapat perbedaan yang signifikan terhadap T1, T2 dan T3.
\end{abstract}

Kata Kunci: Serbuk Buah Mangrove, Dodol, Orgnoletiptik

\begin{abstract}
Mangrove is one of the plants that live along the coast in Indonesia. The role and function of mangroves for ecosystems is very important, in addition to utilization in the fields of ecology, economy, industry, some communities use mangroves as medicine and food, namely the manufacture of lunkhead and waji. The mangrove fruit used in this study was the Pidada mangrove (Sonneratia sp.). The purpose of this study was to determine the effect of the composition of mangrove lunkhead (Sonneratia sp.) on organoleptic tests in the coastal area of Klatakan Village, Situbondo Regency. This study is an experimental study and the experimental design used in this study was a Completely Randomized Design $(C R D)$. The treatment in this study was carried out with the addition of mangrove flour $T 1=$ no addition (control), T2 $=1 \mathrm{tbsp}$ and $T 3=2 \mathrm{tbsp}$. Statistical analysis was carried out in 2 stages, namely univariate and bivariate. In this study, univariate analysis was carried out on each variable and then continued with bivariate analysis using the Kruskal Wallis test. . The characteristics of the panelists which will be described below describe the condition of the panelists under study including gender, age and occupation. There were color differences in the 3 treatments for the composition of mangrove lunkhead (T1, T2 and T3), while in taste and texture characteristics there were no significant differences between $T 1, T 2$ and $T 3$.
\end{abstract}

Keywords: Mangrove Fruit Powder, Dodol, Orgnoletyptic 


\section{PENDAHULUAN}

Daerah pesisir pantai Indonesia banyak tumbuh bakau atau mangrove.M angrove adalah penyususn ekosistem pesisir dengan peranan yang penting bagi ekologi, karena memiliki produktiv itas paling tinggi dibandingkan ekosist em lainnya. Secara ekologi ekosistem mangrove memiliki fungsi antara lain sebagai pencegah abrasi pantai, habitat detritus, perangkap sedimen dan mengabsorbsi logam berat dan cemaran laut (Farhaeni, 2016). Secara umum mangrove yang hidup di daerah terluar didominasi jenis Sonneratia alba, Avicennia alba dan Avicennia marina (Halidah dan Harwiyaddin, 2013).

Pemanfaatan mangrove untuk bahan kosmetik, obat-obatan, makanan dan minuman sudah ada sejak dulu sebagai kearifan masyarakat yang mendiami sekitar ekosistem pantai. Seiring waktu belum ada perkembangan lebih lanjut dan kurangnya informasi tentang pemanfaatannya sehingga banyak yang belum termanfaatkan dengan baik. Purnomobasuki (2004) menyatakan bahwa daerah Jawa, Sulawesi dan Maluku melakukan pemanfaatan mangrove secara tradisional menjadi produk obat-obatan, minuman dan bahan baku kue tradisional seperti dodol dan waji. Hal ini belum dikembangakan di semua daerah karena belum banyak pengetahuan tentang potensi dan manfaat tumbuhan mangrove sebagai sumber pangan fungsional dan sebagai bahan pangan.

Menurut Hossain, et al. 2012 Buah Sonneratia mengandung polifenol, flavonoid, antosianin dan vitamin $\mathrm{C}$ dan kapasitas total (280,8 GAME atau 310,24 AAE / g ekstrak). S. alba adalah salah satu jenis mangrove yang tidak beracun dan mudah cara pengolahannya bahkan buahnya bisa langsung dikonsumsi. Buah muda memiliki rasa asam dan biasanya dibuat sirup atau jus, sedangkan buah yang sudah tua sebagai bahan baku pembuatan kue tradisional seperti dodol dan waji.

Berdasarkan fungsi dan kandungannya buah mangrove dapat di konsumsi dan dibuat olahan kue tradisional misalnya dodol. Dodol adalah salah satu keu tradisional yang memiliki tekstur kenyal, manis dan berminyak dan dapat disimpan dalam waktu yang relatif lama ( \pm 1-3 bulan). Tujuan dari penelitian ini untuk mengetahui pengaruh komposisi pembuatan dodol mangrove (Sonneratia sp.) terhadap uji organoleptik Di Daerah Pesisir Desa Klatakan Kabupaten Situbondo. 


\section{METODE PENELITIAN}

Penelitian ini merupakan penelitian ekperimen dengan rancangan acak lengkap (RAL). Perlakuan dalam penelitian ini dilakukan dengan penambahan tepung mangrove $\mathrm{T} 1=$ tidak ada penambahan (kontrol), $\mathrm{T} 2=1$ sdm dan T3=2 sdm.

Tabel 1. Komposisi Dodol Mangrove

\begin{tabular}{|c|c|c|c|c|}
\hline No & Bahan & T1 & $\mathrm{T} 2$ & T3 \\
\hline 1 & $\begin{array}{c}\text { Tepung } \\
\text { buah } \\
\text { mangrove }\end{array}$ & - & $\begin{array}{c}1 \\
\mathrm{sdm}\end{array}$ & $\begin{array}{c}2 \\
\mathrm{sdm}\end{array}$ \\
\hline 2 & $\begin{array}{l}\text { Tepung } \\
\text { Ketan } \\
\text { (gram) }\end{array}$ & 300 & 300 & 300 \\
\hline 3 & $\begin{array}{l}\text { Tepung } \\
\text { Beras } \\
\text { (gram) }\end{array}$ & 300 & 300 & 300 \\
\hline 4 & $\begin{array}{l}\text { Gula Jawa } \\
\text { (gram) }\end{array}$ & 300 & 300 & 300 \\
\hline 5 & $\begin{array}{l}\text { Santan kela } \\
\text { pa kental (m } \\
\text { 1) }\end{array}$ & 900 & 900 & 900 \\
\hline
\end{tabular}

Analisis statistik dilakukan 2 tahap yaitu univariat dan bivariat. Dalam penelitian ini analisis univariat dilakukan pada tiap variabel dari hasil penelitian dan mendeskripsikan setiap variabel dengan cara membuat tabel distribusi frekuensi, diantaranya hasil uji kesukaan organoleptik dodol mangrove. Kemudian dilanjutkan analisis bivariate menggunakan uji Kruskal Wallis untuk mengetahui perbedaan komposisi pembuatan dodol mangrove.

Penelitian ini dilakukan di daerah Pesisir Desa Klatakan Kabupaten Situbondo dari bulan Desember 2019 sampai September 2020.

Alat yang digunakan yaitu kompor, wajan, saringan, pengaduk, timbangan, sendok, piring, wadah plastik dan plastik. Bahan baku penelitian adalah buah mangrove dari Spesies Sonneratia sp. yang diambil dari Desa Klatakan Kabupaten Situbondo. Saat penelitian buah mangrove dari Spesies Sonneratia sp. jumlahnya sedikit sehingga kami membeli tepung mangrove kepada masyarakat sekitar pesisir dengan jenis yang sama.

\section{Prosedur pembuatan dodol mangrove}

Langkah awal dalam penelitian ini adalah melakukan survei lapangan untuk mengetahui jenis-jenis mangrove yang tumbuh di Desa Klatakan Kabupat en Situbondo. Hasil identifikasi mangrove yang telah dilakukan selanjut nya diambil salah satu jenis buah mangrove dari Spesies Sonneratia sp. atau biasa disebut buah bogem. Buah bogem yang dapat digunakan yaitu matang dan daging buahnya lunak 
Prosedur pembuatan dodol adalah menyiapkan alat dan bahan yang digunakan, Santan yang digunakan adalah santal kental pada perasan 3 kali dan dilakukan pemanasan hingga diperoleh minimal $900 \mathrm{ml}$, Campurkan semua bahan dalam wajan tanpa dipanaskan supaya bahan tercampur sempurna (perlakuan: kontrol/ tanpa mangrove, tepung buah mangrove 1 sendok dan tepung buah mangrove 2 sendok), Hidupkan kompor dengan api kecil dan aduk adonan mangrove hingga mengental dengan pengadukan terus menerus kurang lebih 2.5 jam (indikator: adonan mengental, berwarna coklat gelap, terbentuk minyak kelapa dan mengeluarkan aroma khas), Adonan dodol yang mengental ditempatkan pada wadah yang sudah diberi alas plastik (tidak boleh ditutup sebelum dingin).

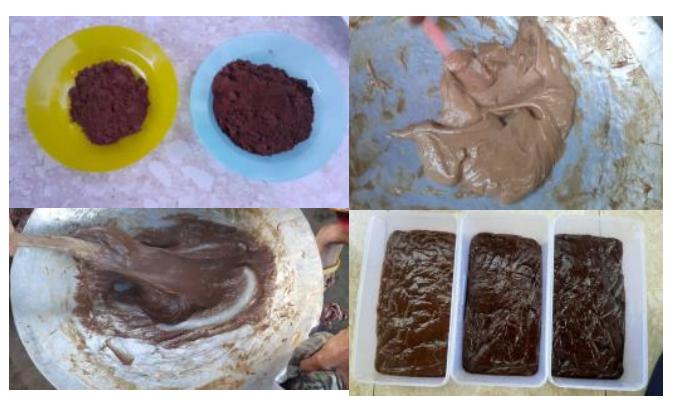

Gambar 1. Serbuk Buah Mangrove dan Adonan Dodol

\section{Uji organoleptik}

Uji organoleptik sebagai alat ukur untuk mengetahui tingkat kesukaan atau kelayakan produk kepada panelis atau konsumen. Metode hedonik (uji kesukaan) yang diuji meliputi warna, aroma, tekstur dan rasa dari dodol mangrove (Rampengan dkk, 1985). Panelis mengisi kusioner dengan memberikan penilaian yang tertuang dalam angka sesuai dengan tingkat kesukaan dari masing-masing panelis. Rentangan skor yang digunakan yaitu 5 (sangat suka), 4 (suka), 3 (agak suka), 2 (tidak suka), 1 (sangat tidak suka).

Pengumpulan data dilakukan setelah pengolahan bahan baku menjadi dodol mangrove dan validasi kualitas. Setelah itu, dilanjutkan dengan menyebarkan kusioner untuk mengetahui uji organoleptik dari tingkat kesukaan panelis terhadap produk dodol mangrove. Analisis data dari kusioner yang telah diisi oleh panelis selanjutnya dianalisis secara statistik univariat dan bivariat. 
HASIL DAN PEMBAHASAN

\section{Gambaran Umum Objek Penelitian}

Komposisi yang diteliti dalam penelitian ini adalah tepung buah mangrove, tepung ketan, tepung beras, gula jawa dan santan kelapa.

Tahapan penelitian ini adalah pengujian organoleptik. Responden pada uji organoleptik sebanyak 25 panelis. Penilaian pada masing - masing produk menggunakan 4 skala tingkat kesukaan yaitu:

1 : Sangat tidak menarik/ Sangat tidak enak/ Sangat tidak kenyal

2 : Tidak menarik/ Tidak enak/

Tidak kenyal

3 : Warna menarik/ Enak/ Kenyal

4 : Sangat menarik/ Sangat Enak/

Sangat kenyal

Dengan tiga karakteristik

penilaian (Warna, Rasa dan

Tekstur).

\section{Hasil Organoleptik}

\section{Karakteristik Panelis}

Panelis yang dipilih dalam uji organoleptik merupakan masyarakat yang ada di sekitar lokasi pengambilan buah mangrove, sehingga sudah familier terhadap rasa dari buah mangrove. Kriteria panelis meliputi jenis kelamin (Laki-laki dan perempuan), umur (20-50 tahun) dan pekerjaan (IRT dan Mahasiswa).

\section{Panelis menurut jenis kelamin}

Tabel 2. Panelis uji organoleptik sesuai jenis kelamin

\begin{tabular}{ccc}
\hline $\begin{array}{c}\text { Jenis } \\
\text { Kelamin }\end{array}$ & Jumlah & $\begin{array}{c}\text { Presentase } \\
(\boldsymbol{\%})\end{array}$ \\
\hline Laki - laki & 5 & 20 \\
Perempuan & 20 & 80 \\
Total & 25 & 100 \\
\hline
\end{tabular}

Pada tabel 2 karakteristik panelis menurut jenis kelamin terdapat $20 \%$ panelis laki-laki yaitu sebanyak 5 orang dan $80 \%$ panelis perempuan yaitu sebanyak 20 orang. Total panelis adalah 25 orang dengan presentase $100 \%$.

\section{Panelis menurut usia}

Tabel 3. Panelis menurut usia

\begin{tabular}{ccc}
\hline Usia & Jumlah & Presentase \\
\hline $20-30$ & 9 & 36 \\
$31-40$ & 12 & 48 \\
$41-50$ & 4 & 16 \\
Total & 25 & 100 \\
\hline
\end{tabular}

Data karakteristik panelis berdasarkan usia, diperoleh angka sebesar $36 \%$ untuk panelis yang berumur 20-30 tahun dengan jumlah 9 orang. Panelis yang berumur 31-40 tahun sebesar $48 \%$ dengan jumlah 12 orang. Panelis yang berumur 41-50 tahun sebesar $16 \%$ dengan jumlah 4 orang. 


\section{Panelis menurut pekerjaan}

Tabel 4. Panelis menurut pekerjaan

\begin{tabular}{ccc}
\hline Pekerjaan & Jumlah & Presentase \\
\hline IRT & 16 & 64 \\
Mahasiswa & 9 & 36 \\
Total & 35 & 100 \\
\hline
\end{tabular}

Panelis menurut pekerjaan dibagi menjadi tiga kelompok yaitu IRT dan mahasiswa. Panelis dengan pekerjaan IRT sebanyak $64 \%$ dangan jumlah 16 orang dan Mahasiswa sebanyak $36 \%$ dangan jumlah 9 orang.

\section{Karakteristik Organoleptik dalam}

\section{Beberapa Komposisi}

\section{Karakteristik organoleptik}

dalam penelitian ini yaitu pengujian pada tiga komposisi dengan tiga karakteristik penilaian yang diataranya : warna, rasa dan tekstur.

\section{Karakteristik Rasa}

Rasa merupakan tanggapan indra terhadap saraf, seperti manis, pahit, asam dan asin. Rasa pada produk sangat berpengaruh pada kesukaan seseorang. Hasil dari pengujian tiga komposisi menghasilkan rerata kesukaan rasa pada produk dodol mangrove. Hasil dari uji Kruskall wallis adalah $\mathrm{p}$-value $=0.601>0,05$ maka dapat disimpulkan bahwa tidak ada perbedaan antara komposisi terhadap parameter mutu organoleptik rasa.

\section{Karakteristik Warna}

Warna dapat memperbaiki dan memberikan daya tarik pada makanan, warna juga berpengaruh terhadap kesukaan pada produk. Penelitian pada warna dodol mangrove dilakukan pada tiga sampel yang menghasilkan rerata kesukaan warna pada kripik mangrove. Hasil uji Kruskal wallis p-value $=0.000$ $<$ 0,05 maka dapat disimpulkan bahwa ada perbedaan antara komposisi terhadap parameter mutu organoleptic warna. Jika dilihat dari nilai Mean Rank menunjukkan T1 lebih tinggi dibandingkan T2 dan T3.

\section{Karakteristik Tekstur}

Tekstur dapat memperbaiki dan memberikan daya tarik pada makanan, Tekstur juga berpengaruh terhadap kesukaan pada produk. Penelitian pada tekstur dodol mangrove dilakukan pada tiga sampel yang menghasilkan rerata kesukaan tekstur pada dodol mangrove. Hasil uji Kruskal wallis p-value $=0.532$ > 0,05 maka dapat disimpulkan bahwa tidak ada perbedaan antara komposisi terhadap parameter mutu organoleptik tekstur. 
Pengaruh Komposisi Pembuatan Dodol Mangrove Terhadap Uji Organoleptik

Dodol merupakan jenis makanan tradisional yang masuk dalam kategori makanan dengan rasa manis. Pengolahan dodol memiliki tingkat yang cukup sulit untuk bisa menghasilkan kualitas dodol dengan rasa dan tekstur yang baik. Oleh karena itu, membutuhkan keahlian khusus dan komposisi yang pas. Secara umum pembuatan dodol terdiri dari tepung ketan, tepung beras, gula jawa, gula pasir, santan dan garam. Selama proses pengadukan adonan dodol biasanya menggunakan api kecil supaya tidak lengket dan menjadi kerak pada bagian bawah yang bisa menyebabkan rasa pahit pada adonan dodol. Pengadukan secara terus menerus hingga matang pada adonan sangat penting untuk mengahiskan prosuk dodol yang bagus. Lama waktu yang dibutuhkan dalam proses pembuatan dodol kurang lebih 4 jam dan setelah adonan dingin maka tektur akan berubah padat dan kental dengan warna kecoklatan.

Berdasarkan hasil uji organleptik menggunakna panca indra dodol mangrove yang dhasilkan memiliki perbedaan dengan dodol yang tanpa pemberian serbuk buah mangrove walaupun sama-sama kecoklatan. T1 yaitu dodol tanpa diberi serbuk buah mangrove memiliki tekstur kenyal, warna coklat agak muda dan rasa manis. T2 adalah dodol dengan penambahan serbuk buah mangrove sebanyak $1 \mathrm{sdm}$ memiliki tekstur kenyal, warna coklat pekat dan rasa manis-pahit. T3 merupakan dodol dengan penambahan serbuk buah mangrove sebanyak $2 \mathrm{sdm}$ dan memiliki tekstur kenyal, warna coklat tua dan rasa manis-agak pahit.

Tekstur kenyal pada dodol disebabkan oleh adanya penambahan tepung ketan yang memberikan ciri khas kental pada adonan. Rasa manis dikarenakan adanya penambahan gula pasir dan gula jawa, sedangkan rasa gurih dan berminyak karena adanya enambahan garam dan santan yang dicampurkan pada adonan.

Hasil dari uji kruskall wallis adalah $\mathrm{p}$-value $=0.601>0,05$ menunjukkan tidak ada perbedaan rasa dengan dodol yang ditambahkan bahan baku tepung / serbuk mangrove. Hasil uji Kruskal wallis p-value $=0.532>$ 0,05 maka dapat disimpulkan bahwa tidak ada perbedaan antara komposisi T1, T2 dan T3 terhadap parameter mutu organoleptik tekstur. 


\section{SIMPULAN DAN SARAN}

Berdasarkan hasil penelitian yang dilakukan dapat disimpulkan sebagai berikut:

1. Jenis - jenis mangrove yang tersedia di Kawasan Wisata Kampung Blekok pesisir desa klatakan yaitu Api-api (Avicennia sp.), Lindur atau Bako (Bruguiera gymnorrhiza), Pidada (Sonneratia caseolaris) Rizophora sp. , Xylocarpus sp, Ceriops sp. dan Excoecaria sp.

2. Ada perbedaan warna pada 3 perlakuan komposisi pembuatan dodol mangrove (T1, T2 dan T3), sedangkan pada karakteristik rasa dan tekstur tidak terdapat perbedaan yang signifikan terhadap T1, T2 dan T3.

\section{DAFTAR PUSTAKA}

Chrissanty AP. Penurunan Kadar Tanin Pada Buah MangroveJenis Brugueira gymnorrhiza, Rhyzophora stylosa dan Avicennia marina untuk Diolah Menjadi Tepung Mangrove. Jurnal Industria:Vol. 1(1);31 39.
Farhaeni M. 2016. Komodifikasi Ragam Buah Mangrove untuk Pemberdayaan Masyarakat Pesisir di Desa Tuban, Kecamatan Kuta, Kabupaten Badung Bali. J of AN1MAGE: Vol 1(1);21-27.

Mulyatun. 2018. Pemberdayaan Masyarakat Pesisir Berbasis Potensi Lokal; Alternatif Ketahanan Pangan Berupa Tepung Magrove. DIMAS: Vol 18(2).

Paputungan Z, Wonggo D, Kaseger EB. 2017. Uji Fitokimia dan Aktivitas Antioksidan Buah Mangrove Sonneratia alba Di Desa Nunuk Kecamatan Pinolosian Kabupaten Bolaang Mongondow Selatan. Jurnal Media Teknologi Hasil Perikanan: Vol 5(3),96-102.

Sahil J, Soamole I. 2013. Pemanfaatan Buah Mangrove Sebagai Sumber Makanan Alternatif di Halmahera Barat, Maluku Utara. BIOGENESIS:Vol 1(2);91-96.

Subekti S. 2012. Pengelolaan Mangrove Sebagai Salah Satu Keanekaragaman Bahan Pangan. Prosiding SNST ke-3: ISBN 978-602-99334-1- 
